\title{
Classification of Streptomyces griseus (Krainsky 1914) Waksman and Henrici 1948 and related species and the transfer of 'Microstreptospora cinerea' to the genus Streptomyces as Streptomyces yanii sp. nov.
}

\author{
Zhiheng Liu, ${ }^{1}$ Yanlin Shi, ${ }^{1}$ Yamei Zhang, ${ }^{1}$ Zhihong Zhou, ${ }^{1}$ Zhitang Lu, ${ }^{1}$ \\ Wei Li, ${ }^{1}$ Ying Huang, ${ }^{1}$ Carlos Rodríguez ${ }^{2}$ and Michael Goodfellow ${ }^{2}$ \\ ${ }^{1}$ State Key Laboratory of Microbial Resources, Institute of Microbiology, Chinese Academy of \\ Sciences, Beijing 100080, People's Republic of China \\ ${ }^{2}$ School of Biology, King George Vlth Building, University of Newcastle, Newcastle upon Tyne \\ NE1 7RU, UK
}

Correspondence Michael Goodfellow m.goodfellow@ncl.ac.uk

\begin{abstract}
A soil actinomycete, strain $80-133^{\top}$, with the non-validly published name 'Microstreptospora cinerea', was the subject of a polyphasic study designed to clarify its taxonomic status. Comparative 16S rRNA gene sequence studies indicated that the organism belonged to the genus Streptomyces, a result in line with previous chemotaxonomic and morphological data. The strain belonged to the Streptomyces griseus clade, but could be distinguished from representatives of species assigned to this taxon by using DNA-DNA relatedness and phenotypic data. In light of these findings, it is proposed that the organism should be recognized as a novel species of the genus Streptomyces. The name proposed for this taxon is Streptomyces yanii sp. nov., with isolate $80-133^{\top}\left(=\mathrm{AS} 4.1146^{\top}=\mathrm{JCM} 3331^{\top}\right)$ as the type strain. It was also shown that representative strains of Streptomyces argenteolus, Streptomyces caviscabies, S. griseus and Streptomyces setonii belong to the same genomic species and have key phenotypic properties in common. It is proposed that $S$. caviscabies and $S$. setonii should be considered as later heterotypic synonyms of S. griseus and that S. argenteolus AS $4.1693^{\top}$ should also be assigned to this taxon.
\end{abstract}

It is clear from 16S rRNA gene sequence data that the type strains of Streptomyces caviscabies Goyer et al. 1996, Streptomyces griseus (Krainsky 1914) Waksman and Henrici 1948 and Streptomyces setonii (Millard and Burr 1926) Waksman 1953 form a distinct clade in the Streptomyces tree together with representative strains of Streptomyces sanglieri Manfio et al. 2003. Streptomyces argenteolus AS $4.1693^{\mathrm{T}}$ also belongs to the $S$. griseus clade. This organism is considered to be the type strain of S. argenteolus, a taxon that is incorrectly attributed to Tresner et al. (1961) in the Approved Lists of Bacterial Names (Skerman et al., 1980) and in the wider microbiological literature (Shirling \& Gottlieb, 1968; Williams et al., 1989; Manfio et al., 2003). This organism was first described in the patent literature (Perlman et al., 1955; Fried et al., 1958). S. griseus and its near relatives show close phylogenetic relationships with

Published online ahead of print on 1 March 2005 as DOI 10.1099/ ijs.0.63654-0.

The GenBank/EMBL/DDBJ accession number for the $16 \mathrm{~S}$ rRNA gene sequence of Streptomyces yanii AS $4.1146^{\top}$ is $\mathrm{AB} 015854$. several species of Streptomyces with validly published names, notably Streptomyces laceyi Manfio et al. 2003, Streptomyces peucetius Grein et al. 1963, Streptomyces purpureus (Matsumae and Hata 1968) Goodfellow et al. 1986b and Streptomyces venezuelae Ehrlich et al. 1948.

The taxonomy of some members of the S. griseus clade has been the source of considerable confusion, as exemplified by the proposal that $S$. griseus NRRL-ISP $5236^{\mathrm{T}}$ and $S$. setonii NRRL-ISP $5395^{\mathrm{T}}$ should be recognized as heterotypic synonyms of Streptomyces anulatus (Williams et al., 1989) and by the assignment of S. argenteolus NRRL-ISP $5226^{\mathrm{T}}$ to the Streptomyces antibioticus and Streptomyces chromofuscus species-groups in the respective numerical phenetic surveys of Kämpfer et al. (1991) and Williams et al. (1983). It is now apparent that additional comparative studies are needed to resolve the finer taxonomic relationships between members of the $S$. griseus clade, especially since representative strains of $S$. argenteolus, S. caviscabies, S. griseus and S. setonii share key morphological features (Shirling \& Gottlieb, 1968, 1969; Goyer et al., 1996) and have identical 
or nearly identical 16S rRNA gene sequences (Manfio et al., 2003). It is also evident from the present study that the strain previously described as 'Microstreptospora cinerea' belongs to the S. griseus $16 \mathrm{~S}$ rRNA gene clade.

The monospecific genus 'Microstreptospora' was proposed by Yan et al. (1983, 1987) for an actinomycete, strain $80-133^{\mathrm{T}}$, which formed single or short chains of spores on the substrate mycelium, chains of spores on aerial hyphae and had whole-organism hydrolysates rich in LLdiaminopimelic acid. The organism was classified as ' $M$. cinerea', but was subsequently considered to be closely related to the genus Elytrosporangium (Itoh et al., 1987), a later synonym of the genus Streptomyces (Goodfellow et al., 1986a). T. Itoh and colleagues were of the view that strain $80-133^{\mathrm{T}}$ should be classified as belonging to the genus Streptomyces as it had chemical and morphological properties that were typical of members of this taxon. The binomial ' $M$. cinerea' is not cited in the Approved Lists of Bacterial Names (Skerman et al., 1980) and hence has no formal standing in nomenclature.

The present study was designed to establish the taxonomic position of ' $M$. cinerea' strain $80-133^{\mathrm{T}}$ and to clarify the taxonomy of members of the S. griseus clade by using a combination of genotypic and phenotypic data. It is evident from the resultant data that the representatives of $S$. argenteolus, S. caviscabies and S. setonii should be classified as S. griseus, and that strain $80-133^{\mathrm{T}}$ forms a distinct centre of taxonomic variation in the genus Streptomyces, for which the name Streptomyces yanii sp. nov. is proposed.

Strain $80-133^{\mathrm{T}}$ and the other strains included in the DNA-DNA relatedness studies, namely $S$. argenteolus AS $4.1693^{\mathrm{T}}$, S. caviscabies DSM $41811^{\mathrm{T}}$, S. griseus AS $4.1419^{\mathrm{T}}$ and AS 4.1321, S. laceyi AS 4.1832 ${ }^{\mathrm{T}}$, S. sanglieri AS $4.1831^{\mathrm{T}}$, S. setonii AS $4.1774^{\mathrm{T}}$, S. peucetius AS $4.1799^{\mathrm{T}}$, S. purpureus AS $4.1225^{\mathrm{T}}$ and S. venezuelae AS $4.1307^{\mathrm{T}}$, were maintained as suspensions of spores and mycelial fragments in glycerol $\left(20 \%\right.$, v/v) and on Gauze's agar $\left(1 \mathrm{~g} \mathrm{KNO}_{3}, 0.5 \mathrm{~g} \mathrm{~K}_{2} \mathrm{HPO}_{4}\right.$, $0.5 \mathrm{~g} \mathrm{MgSO}_{4} .7 \mathrm{H}_{2} \mathrm{O}, 0.5 \mathrm{~g} \mathrm{NaCl}, 10 \mathrm{mg} \mathrm{FeSO}$, $20 \mathrm{~g}$ starch, $30 \mathrm{~g}$ agar, 1 litre distilled water) at room temperature. Biomass for the molecular systematic studies was prepared from 7-day-old cultures grown on Gauze's agar at $30^{\circ} \mathrm{C}$. Genomic DNA was extracted from the biomass and purified following an established procedure (Kim et al., 1998). The undisturbed arrangement of hyphae, notably aerial hyphae, and the spore chain morphology of strains $80-133^{\mathrm{T}}$ and AS $4.1693^{\mathrm{T}}$ were observed on Gauze's agar after 7 days, using the coverslip technique of Kawato \& Shinobu (1959). All of the strains were examined by using a range of phenotypic tests according to standard procedures (Williams et al., 1983).

Purified genomic DNA from strain $80-133^{\mathrm{T}}$ was sequenced according to a standard procedure (Kim et al., 1998). The resultant sequence was aligned manually with corresponding almost-complete sequences of representatives of available Streptomyces species that that been retrieved from
GenBank/EMBL/DDBJ using the CLUSTAL_X program (version 1.64b; Thompson et al., 1997). The resultant dataset was examined by using the least-squares (Fitch \& Margoliash, 1967), maximum-likelihood (Felsenstein, 1981), maximum-parsimony (Kluge \& Farris, 1969) and neighbour-joining (Saitou \& Nei, 1987) tree-making algorithms from the PHYLIP suite of programs (Felsenstein, 1993). Evolution distance matrices for the least-squares and neighbour-joining methods were generated according to Jukes \& Cantor (1969). Tree topologies were evaluated by a bootstrap analysis based on 1000 resamplings of the neighbour-joining dataset by using the SEQBOOT and CONSENSE programs from the PHYLIP package (Felsenstein, 1993). A partial nucleotide sequence (120 bp) from the variable $\gamma$-region of the 16S rRNA gene of the tested strain was compared with corresponding nucleotide sequences of nearly 500 strains belonging to the genus Streptomyces retrieved from GenBank (http://www.ncbi.nlm.nih.gov). A phylogenetic tree based on these partial nucleotide sequences was constructed by using the neighbour-joining algorithm (Saitou \& Nei, 1987). DNA-DNA relatedness studies were carried out (Table 1) by using the thermal denaturation procedure described by De Ley et al. (1970) and a UV-1206 spectrophotometer (Shimadzu) equipped with a TB-85 thermobath.

Comparison of the almost-complete sequence of strain $80-133^{\mathrm{T}}(1463 \mathrm{nt})$ with corresponding sequences of the reference Streptomyces strains showed that the strain formed a phyletic line within the S. griseus subclade (Fig. 1). The tested organism was also distinguished from representatives of over 500 members of the genus Streptomyces in a comparative study based on the $120 \mathrm{bp} \gamma$-region of the $16 \mathrm{~S}$ rRNA gene (data not shown). It was evident from these studies that the tested strain is a bone fide member of the genus Streptomyces, a conclusion that was supported by chemotaxonomic data drawn from previous studies (Yan et al., 1983, 1987; Itoh et al., 1987). The morphological data acquired in the present investigation are in line with those from these earlier studies in showing that strain 80$133^{\mathrm{T}}$ forms single or short chains of spores on substrate hyphae and aerial hyphae that differentiate into short chains of spores.

Table 1. Percentage DNA-DNA relatedness between representatives of species assigned to the $S$. griseus clade

\begin{tabular}{|lrrrrrrr|}
\hline Strain & $\mathbf{1}$ & $\mathbf{2}$ & $\mathbf{3}$ & $\mathbf{4}$ & $\mathbf{5}$ & $\mathbf{6}$ & $\mathbf{7}$ \\
\hline 1. S. yanii $80-133^{\mathrm{T}}$ & 100 & & & & & & \\
2. S. argenteolus AS $4.1693^{\mathrm{T}}$ & 13 & 100 & & & & & \\
3. S. caviscabies DSM $41811^{\mathrm{T}}$ & 30 & 85 & 100 & & & & \\
4. S. griseus AS $4.1419^{\mathrm{T}}$ & 31 & 94 & 100 & 100 & & & \\
5. S. griseus AS 4.1321 & 16 & 84 & 100 & 100 & 100 & & \\
6. S. sanglieri AS $4.1831^{\mathrm{T}}$ & 33 & 32 & 45 & 36 & 40 & 100 & \\
7. S. setonii AS $4.1774^{\mathrm{T}}$ & 25 & 84 & 84 & 100 & 99 & 48 & 100 \\
& & & & & & & \\
\hline
\end{tabular}




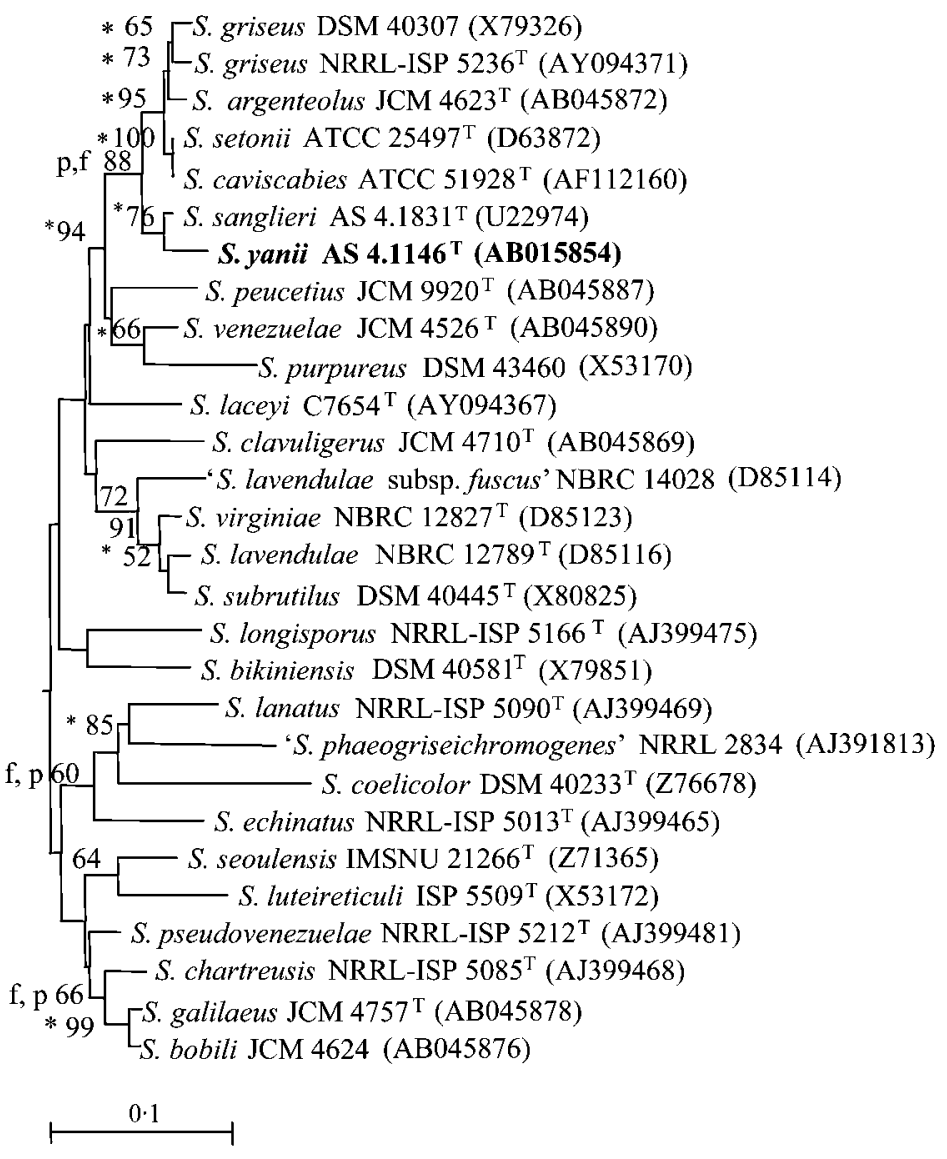

Fig. 1. Neighbour-joining tree showing the position of strain $80-133^{\top}$ in relation to phylogenetically close organisms in the $16 \mathrm{~S}$ rRNA Streptomyces gene tree. Asterisks indicate branches that were also recovered using the least-squares, maximum-likelihood and maximum-parsimony tree-making algorithms. $f$ and $p$ indicate branches that were also recovered using the least-squares and maximum-parsimony methods, respectively. Numbers at nodes are percentage bootstrap values based on a neighbour-joining analysis of 1000 resampled datasets; only values above $50 \%$ are given. Bar, $0 \cdot 1$ substitutions per site.
It is evident from Fig. 1 that strain $80-133^{\mathrm{T}}$ lies at the periphery of the $S$. griseus clade together with the type strain of $S$. sanglieri; the relationship between these strains was underpinned by the results from all of the treemaking algorithms and by a bootstrap value of $76 \%$ in the neighbour-joining analysis. The taxonomic status of the $S$. griseus clade is supported by the results from two of the treemaking algorithms and by a bootstrap value of $88 \%$ in the neighbour-joining analysis. The type strains of S. peucetius, $S$. purpureus and $S$. venezuelae formed a loose phylogenetic group that was closely related to the S. griseus clade; members of these taxa formed a distinct group that was supported by a bootstrap value of $94 \%$ in the neighbourjoining analysis.

Strain $80-133^{\mathrm{T}}$ shared relatively high $16 \mathrm{~S}$ rRNA gene similarity values with other members classified in the $S$. griseus clade, that is, with S. sanglieri AS $4.1831^{\mathrm{T}}(99 \cdot 4 \%), S$. argenteolus AS $4.1693^{\mathrm{T}}(99 \cdot 2 \%)$, S. griseus AS $4.1419^{\mathrm{T}}$ $(99 \cdot 2 \%)$, S. caviscabies DSM $41811^{\mathrm{T}}(99 \cdot 1 \%)$ and S. setonii AS $4.1774^{\mathrm{T}}(99 \cdot 1 \%)$, values that correspond to $8,12,12,13$ and 13 nucleotide differences, respectively. 16S rRNA gene similarities within this range are consistent with the assignment of closely related streptomycetes to distinct species (Sembiring et al., 2000; Manfio et al., 2003). The 16S rRNA gene data are in line with results from previous studies which showed that strain $80-133^{\mathrm{T}}$ had chemical and morphological properties that were typical of members of the genus Streptomyces (Itoh et al., 1987; Yan et al., 1987).

DNA-DNA relatedness studies are used routinely to resolve finer taxonomic relationships between closely related actinomycetes (Kim et al., 2003; Groth et al., 2004). The minimum level of DNA relatedness between strains recommended to define genomic species is $70 \%$ (Wayne et al., 1987), although comprehensive studies on specific groups of streptomycetes indicate that relatedness values above $80 \%$ correspond to species level relatedness within this taxon (Labeda, 1993, 1998; Labeda \& Lyons, 1992). It is evident from Table 1 that strain $80-133^{\mathrm{T}}$ shared relatedness values that were well below these cut-off points with strains of S. argenteolus, S. caviscabies, S. griseus and S. setonii; it was also sharply separated from its nearest phylogenetic neighbour, the type strain of S. sanglieri. Strain $80-133^{\mathrm{T}}$ showed uniformly low DNA-DNA relatedness values with the type strains of S. laceyi (14\%), S. peucetius (14\%), S. purpureus (11\%) and S. venezuelae (16\%). The DNA-DNA pairing data also provide further evidence that strain AS 4.1321, previously designated 'Streptomyces ornatus', belongs to the same genomic species as the type strain of $S$. griseus (Okanishi et al., 1972). 
Table 2. Phenotypic properties that differentiate strain $80-133^{\top}$ from representatives of Streptomyces species classified in the S. griseus clade

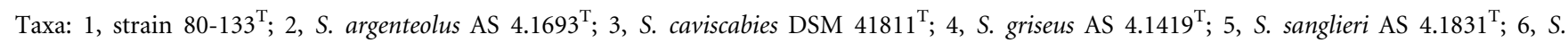
setonii AS $4.1774^{\mathrm{T}}$. Spore chain arrangement data for the reference strains were taken from: Shirling \& Gottlieb (1968), AS 4.1419 ${ }^{\mathrm{T}}$; Goyer

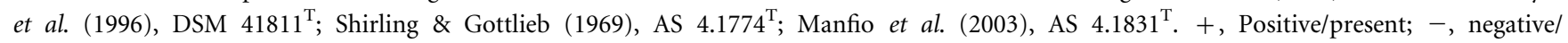
absent. All of the strains were positive for degradation of adenine, hypoxanthine and xanthine; hydrolysis of aesculin and arbutin; utilization of (+)-D-fructose, (+)-D-galactose, (+)-D-glucose, (+)-D-lactose, (+)-D-mannitol, (+)-D-mannose, methyl $\alpha$-D-glucoside, (+)-Draffinose, $(+)$-D-ribose and $(+)$-D-xylose $(1 \%, w / v)$ and acetate, formate, malonate and propionate $(0 \cdot 1 \%$, w/v); and growth in the presence of $7 \% \mathrm{NaCl}$. All of the strains were negative for growth at $45^{\circ} \mathrm{C}$, and production of melanin pigments on either peptone yeast extract iron agar or tyrosine agar.

\begin{tabular}{|c|c|c|c|c|c|c|}
\hline Characteristic & 1 & 2 & 3 & 4 & 5 & 6 \\
\hline \multicolumn{7}{|l|}{$\begin{array}{l}\text { Morphology and pigmentation } \\
\text { on oatmeal agar: }\end{array}$} \\
\hline Aerial spore mass colour & Brown & Yellowish grey & Grey & Yellowish grey & Grey & Yellowish grey \\
\hline Substrate mycelium colour & Grey-black & Yellow-brown & Yellow-brown & $\begin{array}{l}\text { Yellowish grey- } \\
\text { orange }\end{array}$ & Reddish orange & Yellowish grey \\
\hline Diffusible pigment & - & - & - & - & Yellow-brown & - \\
\hline Spore arrangement & $\begin{array}{l}\text { Short to slightly } \\
\text { curved }\end{array}$ & $\begin{array}{l}\text { Long, straight } \\
\text { to flexuous }\end{array}$ & $\begin{array}{l}\text { Long, straight } \\
\text { to flexuous }\end{array}$ & $\begin{array}{l}\text { Long, straight } \\
\text { to flexuous }\end{array}$ & $\begin{array}{l}\text { Long, spiral and } \\
\text { open loops }\end{array}$ & $\begin{array}{l}\text { Long, straight } \\
\text { to flexuous }\end{array}$ \\
\hline Spores on substrate mycelium & + & - & - & - & - & - \\
\hline \multicolumn{7}{|l|}{ Degradation of: } \\
\hline Elastin & - & + & + & + & - & + \\
\hline Tween 20 & - & + & + & + & + & + \\
\hline Tween 80 & - & + & + & + & + & - \\
\hline $\begin{array}{l}\text { Growth in the presence of sodium } \\
\text { azide }(0.01 \%, w / v)\end{array}$ & - & - & - & - & + & - \\
\hline Utilization of citrate & - & + & + & + & + & + \\
\hline
\end{tabular}

It is apparent from Table 2 that strain $80-133^{\mathrm{T}}$ can be distinguished from representatives of species classified in the S. griseus clade by using a combination of phenotypic properties, notably morphological features. Since ' $M$. cinerea' $80-133^{\mathrm{T}}$ can be distinguished from all of these organisms by using a combination of genotypic and phenotypic data, it is proposed that it should be classified as a novel species of the genus Streptomyces. The name proposed for this new taxon is Streptomyces yanii sp. nov.

The results of the present study provide further evidence that the genus Streptomyces as currently constituted is overspeciated (Hatano et al., 2003; Lanoot et al., 2002, 2004, 2005). It is apparent from Table 1 that the type strains of S. argenteolus, S. caviscabies Goyer et al. 1996, S. griseus (Krainsky 1914) Waksman and Henrici 1948 and S. setonii (Millard and Burr 1926) Waksman 1953 share DNA-DNA relatedness values between 84 and $100 \%$, results which provide further evidence for the recognition of the $80 \%$ cut-off for species level relatedness within the genus Streptomyces (Labeda, 1993, 1998; Labeda \& Lyons, 1992). Members of these taxa also have key phenotypic properties in common, notably spore chain morphology (Table 2). It is therefore proposed that S. argenteolus, S. caviscabies and S. setonii are heterotypic synonyms of $S$. griseus, the earliest described of these species with validly published names. An emended description of $S$. griseus is given below.

\section{Description of Streptomyces yanii sp. nov.}

Streptomyces yanii (ya' ni.i. N.L. gen. n. yanii of Yan, named in honour of Dr Xunchu Yan, a Chinese microbiologist).

The description is based on data taken from this and earlier studies (Yan et al., 1983, 1987; Itoh et al., 1987). Aerobic, Gram-positive, non-acid-alcohol-fast actinomycete that forms an extensively branched substrate mycelium and aerial hyphae. The substrate mycelium carries abundant spherical, smooth-surfaced spores (about $2.5 \mu \mathrm{m}$ in diameter) singly or in short chains of 2 to 4 spores on short sporophores. Short chains of ellipsoidal smooth-surfaced spores $(0 \cdot 8 \times 2 \cdot 0 \mu \mathrm{m}$ in diameter) are formed on aerial hyphae. The latter are usually formed only on inorganic media; an abundant grey aerial spore mass is apparent on oatmeal and Krass's No. 1 agars. Forms an abundant grey to black substrate mycelium on Czapek's, Krass's and oatmeal agars. Gelatin and starch are degraded, but not cellulose or tyrosine. Nitrate is reduced. $\mathrm{H}_{2} \mathrm{~S}$ is not formed. Milk is coagulated but not peptonized. Additional phenotypic properties are shown in Table 2. Good growth occurs at $18-35^{\circ} \mathrm{C}$ and $\mathrm{pH} 6-9$. Whole-organism hydrolysates contain major proportions of LL-diaminopimelic acid, glycine, galactose and mannose, and a trace of ribose. The muramic acid of the peptidoglycan is $\mathrm{N}$ acetylated. The predominant isoprenologues are tetra- and 
hexa-hydrogenated menaquinones with nine isoprene units, and the major phospholipids are diphosphatidylglycerol, phosphatidylethanolamine, phosphatidylinositol and phosphatidylinositol mannosides. The $\mathrm{G}+\mathrm{C}$ content of the DNA is $69 \cdot 4 \mathrm{~mol} \%$. The sole strain was isolated from a mud sample collected from a sewage ditch in Zhanjiang City, Guangdong Province, China.

The type strain is $80-133^{\mathrm{T}}\left(=\right.$ AS $\left.4.1146^{\mathrm{T}}=\mathrm{JCM} 3331^{\mathrm{T}}\right)$.

\section{Emended description of Streptomyces griseus (Krainsky 1914) Waksman and Henrici 1948, 948 ${ }^{\mathrm{AL}}$}

Streptomyces griseus (gri'se.us. M.L. masc. adj. griseus grey).

The description is based on data taken from this and earlier studies (Shirling \& Gottlieb, 1968, 1969). Spore chains are rectiflexibiles; the spore surface is smooth. Aerial spore mass colour places the organism in the grey colour series; the reverse side of colonies is grey-yellow. Melanin pigment is not formed nor are soluble pigments produced. Additional phenotypic properties are shown in Table 2 . The $\mathrm{G}+\mathrm{C}$ content of the DNA is $71-72 \mathrm{~mol} \%$. The type strain is ATCC $23921^{\mathrm{T}}\left(=\right.$ AS $4.1419^{\mathrm{T}}=\mathrm{DSM} 40236^{\mathrm{T}}=$ NRRL-ISP $5236^{\mathrm{T}}=\mathrm{JCM} 4047^{\mathrm{T}}=$ NCIMB $\left.13023^{\mathrm{T}}\right)$. Heterotypic synonyms: Streptomyces argenteolus, Streptomyces caviscabies Goyer et al. 1996 and Streptomyces setonii (Millard and Burr 1926) Waksman 1953.

\section{Acknowledgements}

This work was supported through the Chinese Academy of SciencesRoyal Society Exchange Scheme (grant number Q 814) and by the National Natural Science Foundation of China (grant number 30370002). C.R. gratefully acknowledges receipt of a scholarship from the Ecuadorian FUNDACYT (Foundation for Science and Technology) and an Overseas Development Award. The authors are indebted to Dr M. Takeuchi (NBRC, Japan) for providing some of the type strains.

\section{References}

De Ley, J., Cattoir, H. \& Reynaerts, A. (1970). The quantitative measurement of DNA hybridization from renaturation rates. Eur J Biochem 12, 133-142.

Ehrlich, J., Gottlieb, D., Burkholder, P. E., Anderson, L. E. \& Pridham, T. G. (1948). Streptomyces venezuelae n. sp., the source of chloromycetin. J Bacteriol 56, 467-477.

Felsenstein, J. (1981). Evolutionary trees from DNA sequences: a maximum likelihood approach. J Mol Evol 17, 368-376.

Felsenstein, J. (1993). PHYLIP (phylogeny inference package), version 3.5c. Department of Genome Sciences, University of Washington, Seattle, USA.

Fitch, W. M. \& Margoliash, E. (1967). Construction of phylogenetic trees. Science 155, 279-284.

Fried, J., Perlman, D., Langlykke, A. F. \& Titus, E. O. (1958). 16 Alpha-hydroxylation steroids. US Patent 2,855,343. 7 October 1958, US Patent Office.
Goodfellow, M., Williams, S. T. \& Alderson, G. (1986a). Transfer of Elytrosporangium brasiliense Falcão de Morais et al., Elytrosporangium carpinense Falcão de Morais et al., Elytrosporangium spirale Falcão de Morais et al., Microellobosporia cinerea Cross et al., Microellobosporia flavea Cross et al., Microellobosporia grisea (Konev et al.) Pridham and Microellobosporia violacea (Tsyganov et al.) Pridham to the genus Streptomyces, with emended descriptions of the species. Syst Appl Microbiol 8, 48-54.

Goodfellow, M., Williams, S. T. \& Alderson, G. (1986b). Transfer of Kitasatoa purpurea Matsumae and Hata to the genus Streptomyces as Streptomyces purpureus comb. nov. Syst Appl Microbiol 8, 65-66.

Goyer, C., Faucher, E. \& Beaulieu, C. (1996). Streptomyces caviscabies sp. nov., from deep-pitted lesions in potatoes in Québec, Canada. Int J Syst Bacteriol 46, 635-639.

Grein, A., Spalla, C., Di Marco, A. \& Canevazzi, G. (1963). Descrizione e classificazione di un attinomicete (Streptomyces peucetius sp. nova) produttore di una sostanza attivita antitumorale: La daunomicina. G Microbiol 11, 109-118 (in Italian).

Groth, I., Rodriguez, C., Schütze, B., Schmitz, P., Leistner, E. \& Goodfellow, M. (2004). Five novel Kitasatospora species from soil: Kitasatospora arboriphila sp. nov., K. gansuensis sp. nov., $K$. nipponensis sp. nov., $K$. paranensis sp. nov. and $K$. terrestris sp. nov. Int J Syst Evol Microbiol 54, 2121-2129.

Hatano, K., Nishii, T. \& Kasai, H. (2003). Taxonomic re-evaluation of whorl-forming Streptomyces (formerly Streptoverticillium) species by using phenotypes, DNA-DNA hybridization and sequences of gyrB, and proposal of Streptomyces luteireticuli (ex Katoh and Arai 1957) corrig., sp. nov., nom. rev. Int J Syst Evol Microbiol 53, 1519-1529.

Itoh, T., Kudo, T. \& Seino, A. (1987). Chemotaxonomic studies on new genera of actinomycetes proposed in Chinese papers. Actinomycetologica 1, 43-59.

Jukes, T. H. \& Cantor, C. R. (1969). Evolution of protein molecules. In Mammalian Protein Metabolism, vol. 3, pp. 21-132. Edited by H. N. Munro. New York: Academic Press.

Kämpfer, P., Kroppenstedt, R. M. \& Dott, W. (1991). A numerical classification of the genera Streptomyces and Streptoverticillium using miniaturised physiological tests. J Gen Microbiol 137, 1831-1891.

Kawato, M. \& Shinobu, R. (1959). On Streptomyces herbaricolor sp. nov., supplement: a simple technique for microscopical observation. Mem Osaka Univ Lib Arts Educ B8, 114-119.

Kim, S. B., Falconer, C., Williams, E. \& Goodfellow, M. (1998). Streptomyces thermocarboxydovorans sp. nov. and Streptomyces thermocarboxydus sp. nov., two moderately thermophilic carboxydotrophic species from soil. Int J Syst Bacteriol 48, 59-68.

Kim, S. B., Lonsdale, J., Seong, C.-N. \& Goodfellow, M. (2003). Streptacidiphilus gen. nov., acidophilic actinomycetes with wall chemotype I and emendation of the family Streptomycetaceae (Waksman and Henrici $(1943)^{\mathrm{AL}}$ ) emend. Rainey et al. (1997). Antonie van Leeuwenhoek 83, 107-116.

Kluge, A. G. \& Farris, F. S. (1969). Quantitative phyletics and the evolution of anurans. Syst Zool 18, 1-32.

Krainsky, A. (1914). Die Aktinomyceten und ihren Bedeutung in der Natur. Zentralbl Bakteriol Parasitenkd Infektionskr Hyg Abt II 41, 649-688 (in German).

Labeda, D. P. (1993). DNA relatedness among strains of the Streptomyces lavendulae phenotypic cluster group. Int J Syst Bacteriol 43, 822-825.

Labeda, D. P. (1998). DNA relatedness among the Streptomyces fulvissimus and Streptomyces griseoviridis phenotypic cluster groups. Int J Syst Bacteriol 48, 829-832.

Labeda, D. P. \& Lyons, A. J. (1992). DNA relatedness among strains of the sweet potato pathogen Streptomyces ipomoea (Person and 
Martin 1949) Waksman and Henrici 1948. Appl Environ Microbiol 58, 532-535.

Lanoot, B., Vancanneyt, M., Cleenwerck, I., Wang, L., Li, W., Liu, Z. \& Swings, J. (2002). The search for synonyms among streptomycetes by using SDS-PAGE of whole-cell proteins. Emendation of the species Streptomyces aurantiacus, Streptomyces cacaoi subsp. cacaoi, Streptomyces caeruleus and Streptomyces violaceus. Int J Syst Evol Microbiol 52, 823-829.

Lanoot, B., Vancanneyt, M., Dawyndt, P., Cnockaert, M., Zhang, J., Huang, Y., Liu, Z. \& Swings, J. (2004). BOX-PCR fingerprinting as a powerful tool to reveal synonymous names in the genus Streptomyces. Emended descriptions are proposed for the species Streptomyces cinereorectus, S. fradiae, S. tricolor, S. columbiensis, S. filamentosus, S. vinaceus and S. phaeopurpureus. Syst Appl Microbiol 27, 84-92.

Lanoot, B., Vancanneyt, M., Van Schoor, A., Liu, Z. \& Swings, J. (2005). Reclassification of Streptomyces nigrifaciens as a later synonym of Streptomyces flavovirens; Streptomyces citreofluorescens, Streptomyces chrysomallus subsp. chrysomallus and Streptomyces fluorescens as later synonyms of Streptomyces anulatus; Streptomyces chibaensis as a later synonym of Streptomyces corchorusii; Streptomyces flaviscleroticus as a later synonym of Streptomyces minutiscleroticus; and Streptomyces lipmanii, Streptomyces griseus subsp. alpha, Streptomyces griseus subsp. cretosus and Streptomyces willmorei as later synonyms of Streptomyces microflavus. Int J Syst Evol Microbiol 55, 729-731.

Manfio, G. P., Atalan, E., Zakrzewska-Czerwinska, J., Mordarski, M., Rodriguez, C., Collins, M. D. \& Goodfellow, M. (2003). Classification of novel streptomycetes as Streptomyces aureus sp. nov., Streptomyces laceyi sp. nov. and Streptomyces sanglieri sp. nov. Antonie van Leeuwenhoek 83, 245-255.

Matsumae, A., Ohtani, M., Takeshima, H. \& Hata, T. (1968). A new genus of the Actinomycetales: Kitasatoa gen. nov. J Antibiot 21, 616-625.

Millard, W. A. \& Burr, S. (1926). A study of twenty-four strains of Actinomyces and their relation to types of common scab of potato. Ass Appl Biol 13, 580-644.

Okanishi, M., Akagawa, H. \& Umezawa, H. (1972). An evaluation of taxonomic criteria in streptomycetes on the basis of deoxyribonucleic acid homology. J Gen Microbiol 72, 49-58.

Perlman, D., Fried, J., Titus, E. O. \& Langlykke, A. F. (1955). 16 Alpha-hydroxyprogesterone, 16 alpha-hydroxydihydroprogesterone and esters thereof. US Patent 2,709,705. 31 May 1955, US Patent Office.
Saitou, N. \& Nei, M. (1987). The neighbor-joining method: a new method for constructing phylogenetic trees. Mol Biol Evol 4, 406-425.

Sembiring, L., Ward, A. C. \& Goodfellow, M. (2000). Selective isolation and characterisation of members of the Streptomyces violaceusniger clade associated with the roots of Paraserianthes falcataria. Antonie van Leeuwenhoek 78, 353-366.

Shirling, E. B. \& Gottlieb, D. (1968). Cooperative description of the type cultures of Streptomyces. III. Additional species descriptions from first and second studies. Int J Syst Bacteriol 18, 279-392.

Shirling, E. B. \& Gottlieb, D. (1969). Cooperative description of type cultures of Streptomyces. IV. Species descriptions from the second, third and fourth studies. Int J Syst Bacteriol 19, 391-512.

Skerman, V. B. D., McGowan, V. \& Sneath, P. H. A. (1980). Approved lists of bacterial names. Int J Syst Bacteriol 30, 225-420.

Thompson, J. D., Gibson, T. J., Plewniak, F., Jeanmougin, F. \& Higgins, D. G. (1997). The CLUSTAL_X Windows interface: flexible strategies for multiple sequence alignment aided by quality analysis tools. Nucleic Acids Res 25, 4876-4882.

Tresner, H. D., Davies, M. C. \& Backus, E. J. (1961). Electron microscopy of Streptomyces spore morphology and its role in species differentiation. J Bacteriol 81, 70-80.

Waksman, S. A. (1953). Guide to the Classification and Identification of the Actinomycetes and their Antibiotics. Edited by S. A. Waksman \& H. A. Lechevalier. Baltimore: Williams \& Wilkins.

Waksman, S. A. \& Henrici, A. T. (1948). Family III. Streptomycetaceae Waksman \& Henrici. In Bergey's Manual of Determinative Bacteriology, 6th edn, pp. 929-980. Edited by R. S. Breed, E. G. D. Murray \& A. P. Hitchens. Baltimore: Williams \& Wilkins.

Wayne, L. G., Brenner, D. J., Colwell, R. R. \& 9 other authors (1987). Report of the ad hoc committee on reconciliation of approaches to bacterial systematics. Int J Syst Bacteriol 37, 463-464.

Williams, S. T., Goodfellow, M., Alderson, G., Wellington, E. M. H., Sneath, P. H. A. \& Sackin, M. J. (1983). Numerical classification of Streptomyces and related genera. J Gen Microbiol 129, 1743-1813.

Williams, S. T., Goodfellow, M. \& Alderson, G. (1989). Genus Streptomyces Waksman and Henrici 1943, 339 AL. In Bergey's Manual of Systematic Bacteriology, vol. 4, pp. 2452-2492. Edited by S. T. Williams, M. E. Sharpe \& J. G. Holt. Baltimore: Williams \& Wilkins.

Yan, X., Jiang, C. \& Zhang, Y. (1983). A new genus of the order Actinomycetales. Acta Microbiol Sin 23, 289-291 (in Chinese).

Yan, X., Jiang, C. \& Zhang, Y. (1987). Microstreptospora, a new genus of the order Actinomycetales. The Actinomycetes 20, 89-92. 